\title{
Tuberous sclerosis in a child
}

\section{Vijay Baburao Sonawane, V. Kotrashetti, Kapil Bainade, Amit Vatkar, Saili Bunde*}

Department of Pediatrics, D. Y. Patil University, School of Medicine, Navi Mumbai, Maharashtra, India

Received: 15 June 2020

Accepted: 08 July 2020

\section{*Correspondence:}

Dr. Saili Bunde,

E-mail: sailibunde28@gmail.com

Copyright: (C) the author(s), publisher and licensee Medip Academy. This is an open-access article distributed under the terms of the Creative Commons Attribution Non-Commercial License, which permits unrestricted non-commercial use, distribution, and reproduction in any medium, provided the original work is properly cited.

\begin{abstract}
Tuberous Sclerosis (TS) is the most common single gene disorder in children. It has an incidence of 1 in 5800 live births. It is an autosomal dominant genetic multisystemic disease characterized by hamartic development of many organs most notably the brain, heart, kidney, lungs and skin. It results from mutation of TSC1 and TSC 2 gene coding for hamartin and tuberin respectively. Most of the newborns are asymptomatic. In infancy, seizures are the most common symptoms with a high incidence of infantile spasm while children between 2- 10 years neurological symptoms are most frequent with epilepsy, mental retardation and autism. Authors report a 4-year-old male child born of grade 3 consanguineous marriage presented with seizures in form of Infantile Spasm and Skin Lesions.
\end{abstract}

Keywords: Autism, Hamartoma, Infantile spasm, Seizures, Tuberous sclerosis

\section{INTRODUCTION}

Tuberous sclerosis also known as Bourneville's disease is a rare autosomal dominant single gene mutation disorder resulting from mutation of either of the two gene i:e TSC1 or TSC 2 .

It is clinically characterized by the triad of epilepsy, intellectual disability and adenoma sebaceum, therefore, encompassing these features Sherlock coined the term EPILOIA. ${ }^{1}$ For the diagnosis of TS 2 major out of 11 OR 1 major and 2 minor out of 7 minor features should be present or identification of a known pathogenic mutation in TSC1 or TSC2 gene. For probable TSC 1 major feature or 2 or more minor feature should be present.

Major features include hypomelanotic macules, angiofibroma, ungula fibroma, shagreen patch, multiple retinal hamartomas, cortical dysplasia, subependymal nodules, subependymal giant cell astrocytoma, cardiac rhabdomyoma, lymphangioleiomyomatosis, angiomyolipoma. Minor features include confetti skin lesion, dental enamel pit, intraoral fibromas, retinal achromic patch, multiple renal cysts, nonrenal hamartomas. $^{2}$ Authors present a 4-year-old male child with distinctive clinical and radiological features of Tuberous Sclerosis.

\section{CASE REPORT}

Authors report a 4-year-old male child born of grade 3 consanguineous marriage with history of convulsion since 1 month of age and history of epilecalptic spasm 23 times per day. Birth history was normal. On general physical examination red papules suggestive of adenoma sebaceum (Figure 1) were seen on the face mainly near the nasolabialfold.

A well-defined roughened hypermelanotic patch was noted in the lower back and face showing an orange peel appearance indicative of Shagreen patch (Figure 2) were present.

On intraoal examinationn Enamel pitting was present. Patient had global developmental delay. CNS examination was normal. 


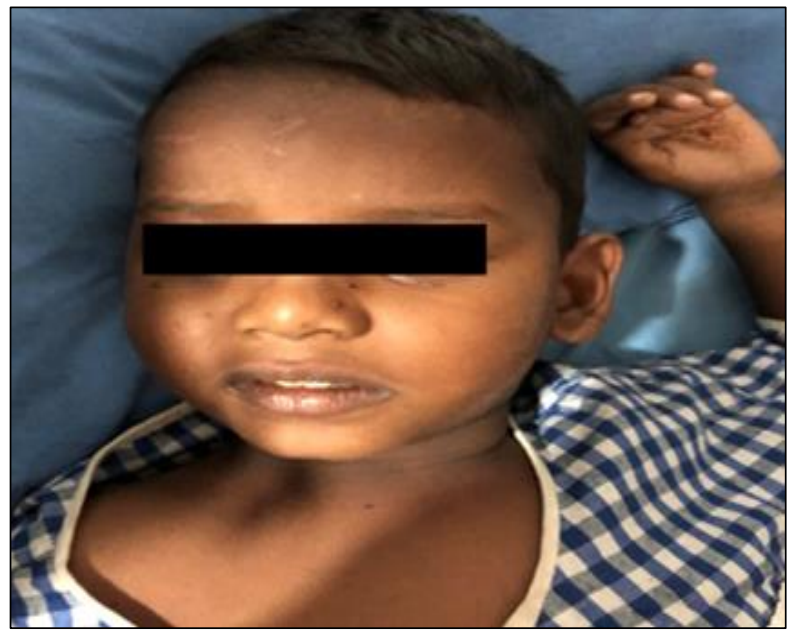

Figure 1: Adenoma sebaceum.

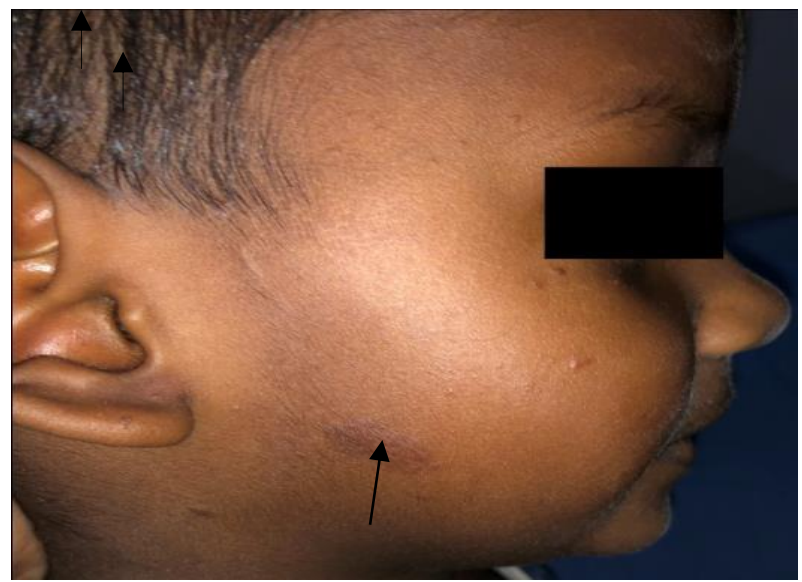

Figure 2: Shagreen patch.

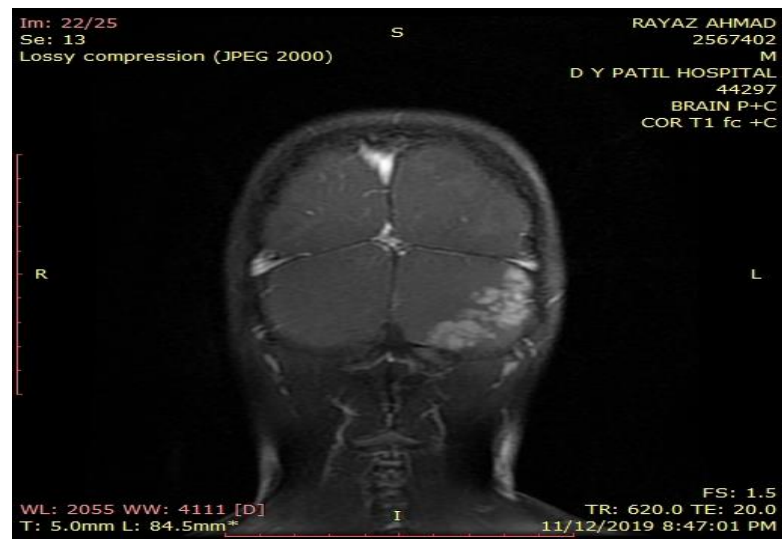

Figure 3: Cortical tubers.

Patient went under certain radiological and hematological investigations. MRI brain showed multiple subependymal nodules (Figure 3, 4 and 5) in bilateral ventricles and multiple FLAIR hyperintense ill-defined lesion in left cerebellar hemisphere and bilateral cerebral hemisphere appearing iso to mildly hyperintense on $\mathrm{T} 1$ and hyperintense on $\mathrm{T} 2$, hyperintense gliotic areas in anterior right internal capsule. 2D echo, USG KUB and ophthal evaluation was normal. EEG showed burst suppression pattern intermittently, high voltage intermittent sharps seen in frontal and parietal region Considering all the above findings the patient was diagnosed as tuberous sclerosis. Patient was started on antiepileptics and follow up was advised.

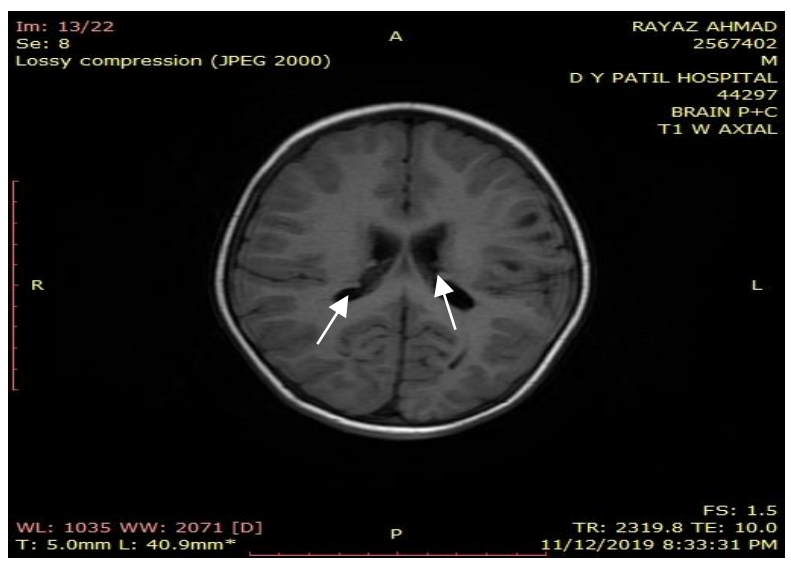

Figure 4: Subependymal nodule and cortical tubers in T1W image.

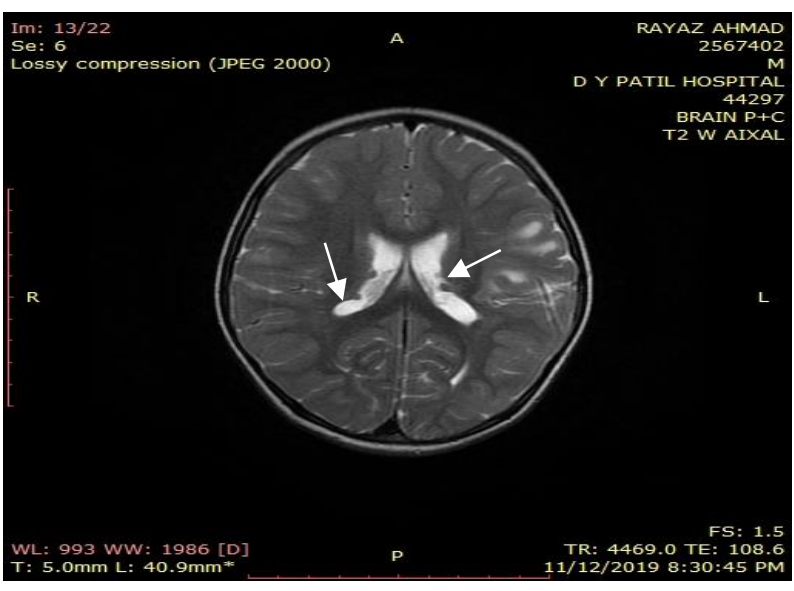

Figure 5: Subependymal nodule and cortical tubers IN T2W image.

\section{DISCUSSION}

TSC is characterized by the development of unusual tumor-like growths (hamartomas) in brain, skin, retina, and viscera. The term "tuberous sclerosis" refers specifically to the presence of multiple sclerotic masses scattered throughout the cerebrum. The diagnosis of TSC is based on the identification of hamartomas in more than one organ system. ${ }^{3}$ The abnormal genes have been localized to one of two sites, the long arm of chromosome 9 (9q34), designated as TSC 1 (encoding hamartin), and the short arm of chromosome 16 (16p 13.3) designated as TSC 2 (encoding tuberin). These gene products form a tumor suppressor complex which drives Rheb (Ras homolog enriched in brain) a member of Ras superfamily into the inactive guanosine diphosphatebound state. When Rheb is in the guanosine triphosphate- 
bound active state, it stimulates the mammalian target of rapamycin (mTOR), an evolutionarily conserved protein kinase and a major effector of cell growth. The mutations in these genes result in constitutive mTOR activation leading to the formation of various growths and hamartomas in various organs of the body. ${ }^{4}$ In a study conducted on 325 TSC individuals, $17 \%$ of the mutations were found in the TSC1gene, $50 \%$ in the TSC2 gene, $4 \%$ unclassified variants, and $29 \%$ with no identifiable mutations. ${ }^{5}$ The presence of two major features or one major and two minor features was considered sufficient for a definitive diagnosis. This case presented with three major features - facial angiofibromas, shagreen patch and subependymal nodules, and one minor features - enamel pitting. ${ }^{6,7}$ Most often the children with TSC begin having seizure in the first month or the first year of life which was seen in our patient. The seizure types include all varieties included in the International League Against Epilepsy except pure absence seizure of classic petit mal. The most frequent seizure types are partial motor, complex partial, and partial secondary generalized, including infantile spasm8. Infantile spasm was the presenting complaint in $69 \%$ of patients in one large study 9 and in $68 \%$ patients in Hunt's study. ${ }^{10}$ Our patient presented with infantile spasm since one month of age. There is an inverse relation between number of cortical tubers in a patient and the age of onset of seizure. The likelihood of the first seizure being an infantile spasm increases in parallel with the total number of tubers $(\mathrm{P}$ $<0.001)$. the frequency and severity of the epileptic seizures are also greater when the number of tubers is higher. In a study of 75 patients with TSC who had sequential MRI brain, the 29 patients who had infantile spasm harbored more cortical tubers than the 26 patients who had other types of generalized seizures. ${ }^{11}$ The management of these patient is usually multidisciplinary. Surgery including dermabrasion and laser treatment may be useful for the treatment of skin lesions. Intervention programs including special schooling and occupational therapy may benefit individuals with special needs and developmental concern. ${ }^{11,12}$ The prognosis of TSC depends on the severity or multiplicity of organ involvement. About a quarter of severely affected infants is thought to die before the age of $10 \%$ and $75 \%$ before 25 years. However, in the case of individuals diagnosed late in life with few cutaneous signs, prognosis depends on the associated internal tumors and cerebral calcifications. $^{13}$

\author{
Funding: No funding sources \\ Conflict of interest: None declared \\ Ethical approval: Not required
}

\section{REFERENCES}

1. Illahi Y, Tanveer S, Khurshid Pasha KA, Naeem A, Ali N. Tuberous sclerosis. Classical presentation in a male patient. NMJ. 2010;2:29-32.

2. Gutmann DH, Aylsworth A, Carey JC, Korf B, Marks J, Pyeritz RE, et al. The diagnostic evaluation and multidisciplinary management of neurofibromatosis 1 and neurofibromatosis 2 . JAMA. 1997;278(1):51-7.

3. Jankar A, Palange P, Purandare V. Tuberous Sclerosis-A Case Report. IJBR. 2014;5(10):649-50.

4. Cheng TS. Tuberous sclerosis complex: an update. Hong Kong J Dermatol Venereol. 2012;20:61-7.

5. Au KS, Williams AT, Roach ES, Batchelor L, Sparagana SP, Delgado MR, et al. Genotype/phenotype correlation in 325 individuals referred for a diagnosis of tuberous sclerosis complex in the United States. Genet Med. 2007;9(2):88-100.

6. Harutunian K, Barbosa de Figueiredo RP, Gay Escoda C. Tuberous sclerosis complex with oral manifestations: A case report and literature review. Medicina Oral, Patología Oral y Cirugia Bucal, 2011;16(4):478-81.

7. Araujo LD, Muniz GB, Santos E, Ladeia JP, Martelli Junior H, Bonan PR. Tuberous sclerosis complex diagnosed from oral lesions. Sao Paulo Med J. 2013;131(5):351-5.

8. Gomez MR, Sampson JR, Whittemore VH, editors. Tuberous sclerosis complex. Oxford University Press; 1999 Jul 15.

9. Crome L. The brain and mental retardation. Br Med Jr. 1960;1:897-904.

10. Donegani G, Gratarolla FR. Wildi E. Tuberous Sclerosis. In: Vinken PJ, Bruyn GW. Eds. Handbook of clinical Neurology, Vol 14: the Phakomatoses. Amsterdam: North Holland; 1972:340-389.

11. Midde ML, Saheb DM. Tuberous sclerosis complex- A case report. Southeast Asian J Case Rep Rew. 2013;2:343-8.

12. Cheng TS. Tuberous sclerosis complex: An update. Hong Kong J Dermatol Venereol. 2012;20:61-7.

13. Jankar AN, Palange PB, Purandare VC. Tuberous sclerosis- A case report. Int J Biomed Res. 2014;5:649-50.

Cite this article as: Sonawane VB, Kotrashetti V, Bainade K, Vatkar A, Bunde S. Tuberous sclerosis in a child. Int J Contemp Pediatr 2020;7:1795-7. 